\title{
Trichogin analogs for retinal drug delivery
}

Marta De Zotti $^{1}$, Ivan Guryanov ${ }^{2}$, Tatiana Tennikova ${ }^{2}$, Madhushree Bhattacharya $^{3}$, Arto Urtti ${ }^{3}$

\author{
${ }^{1}$ University of Padova, Italy \\ ${ }^{2}$ St. Petersburg State University, Russia \\ ${ }^{3}$ University of Helsinki, Finland
}

https://doi.org/10.17952/35EPS.2018.289

In ophthalmology retinal drug therapy is one of the major challenges, because it is hampered by ineffective and/or short-acting drug delivery to the targets [1]. Often these targets are located in intracellular compartments and there is a need of drug delivery systems able to transfer pharmaceutical cargo into retinal cells [2,3]. Many retinal therapeutics are based on proteins and oligonucleotides with poor cell permeability. The development of cell penetrating carriers of farmaceutical cargos can noticeably enhance their therapeutic effect. From this point of view membrane-active trichogin analogs are very promising candidates as components of retinal drug delivery systems [4]. The main disadvantage of thichogin as a cell penetrating peptide (CPP) is its low solubility in aqueous media. In order to increase water solubility, we introducedlysine or 4-aminopiperidine-4-carboxylic acid (Api) residues into the trichogin sequence at different positions (Table 1).

Table 1: Structures of trichogin analogs.

\begin{tabular}{cc}
\hline Peptide & Structure* $^{*}$ \\
\hline Tricogin & $n$ Oct-UGLUGGLUGI-Lol \\
$\mathrm{T}-1$ & $n$ Oct-UGLUKKLUGI-Lol \\
$\mathrm{T}-2$ & $n$ Oct-UGLUKKLUGIL-NH-(CH$)_{2}-\mathrm{NH}_{2}$ \\
$\mathrm{~T}-3$ & $n$ Oct-UGLUGKLUGI-Lol \\
$\mathrm{T}-4$ & $n$ Oct-UGLUKULUGI-Lol \\
$\mathrm{T}-5$ & $n$ Oct-UGLUKLUGI- NH- $\left(\mathrm{CH}_{2}\right)_{2}-\mathrm{NH}-\mathrm{FITC}$ \\
AP-corto & $n$ Oct-UGLUKKLL- NH- $\left(\mathrm{CH}_{2}\right)_{2}-\mathrm{NH}_{2}$ \\
Corto-1 & $n$ Oct-UKKLUGIL- NH-(CH$)_{2}-\mathrm{NH}_{2}$ \\
Corto-2 & $n$ Oct-Toac-GLUGGL-Api-I-Lol \\
T-6 &
\end{tabular}

${ }^{*}$ nOct $=$ n-octanoyl; $\mathrm{U}=$ Aib; Lol = leucinol

To have a possibility for the attachment of a drug some analogs were modified with C-terminal amino group. The influence of the length of the peptide on the membrane activity and cell viability was studied by removal C- or Nterminal parts (peptides Corto- 1 and Corto-2, respectively). For further study of peptide structure and mechanism of cell penetration the analog containing nitroxide spin-labeled amino acid Toac (2,2,6,6-tetramethylpiperidine-1-oxy-4-amino-4-carboxylic acid) was prepared as well [5]. All analogs were synthesized by manual SPPS using either a Rink-amide or a 2-chlorotrityl resin preloaded with Lol or a 1,2-diaminoethane moiety with following modification with FITC label (peptide T-5). NMR conformational analysis of FITC labeled peptide showed no structural changes upon modification and native helical conformation was proved to be maintained (Figure 1). 


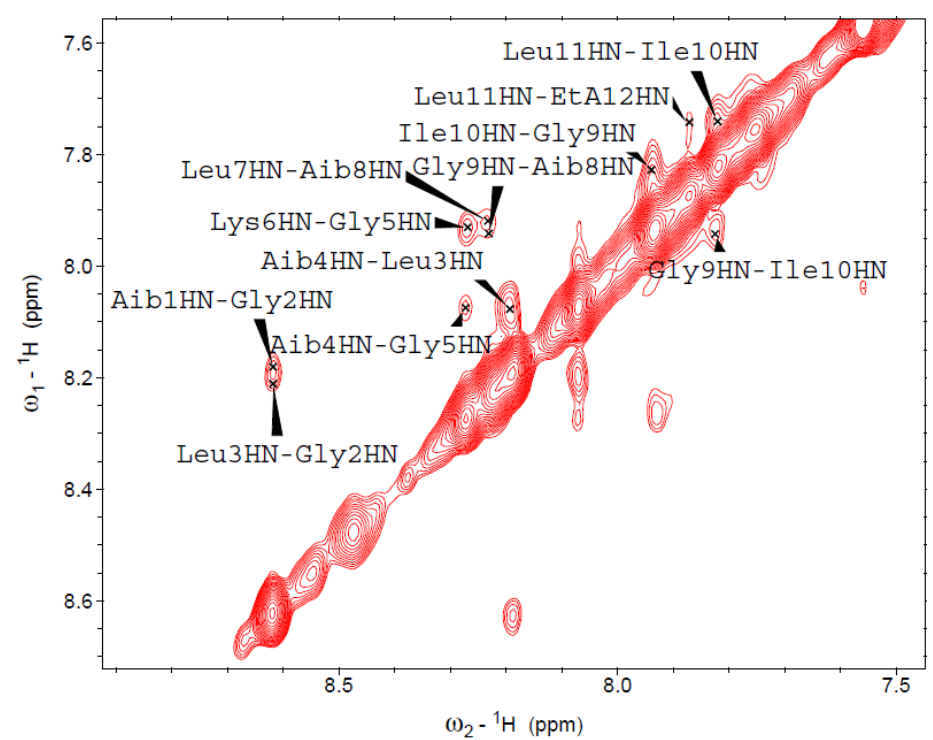

Figure 1: Amide portion of the Noesy spectrum of T-5 in $\mathrm{SDS}-d_{25} \mathrm{H}_{2} \mathrm{O} / \mathrm{D}_{2} \mathrm{O}$ 9:1 (2 mM, $\left.600 \mathrm{MHz}, 303 \mathrm{~K}\right)$. Cross-peaks between corresponding amino acids are evidenced.

Cytotoxicity of peptide-carriers was evaluated for retinal pigment epithelium (ARPE-19) cells. The peptides were dissolved in a small amount of DMSO and then diluted with cell medium to the desired concentration. The cells were treated with peptides for $5 \mathrm{~h}$ and cell viability was evaluated by MTT cytotoxicity assay. Poly L-lysine (PLL) treated and untreated cells were used as positive and negative control, respectively (Figure 2).

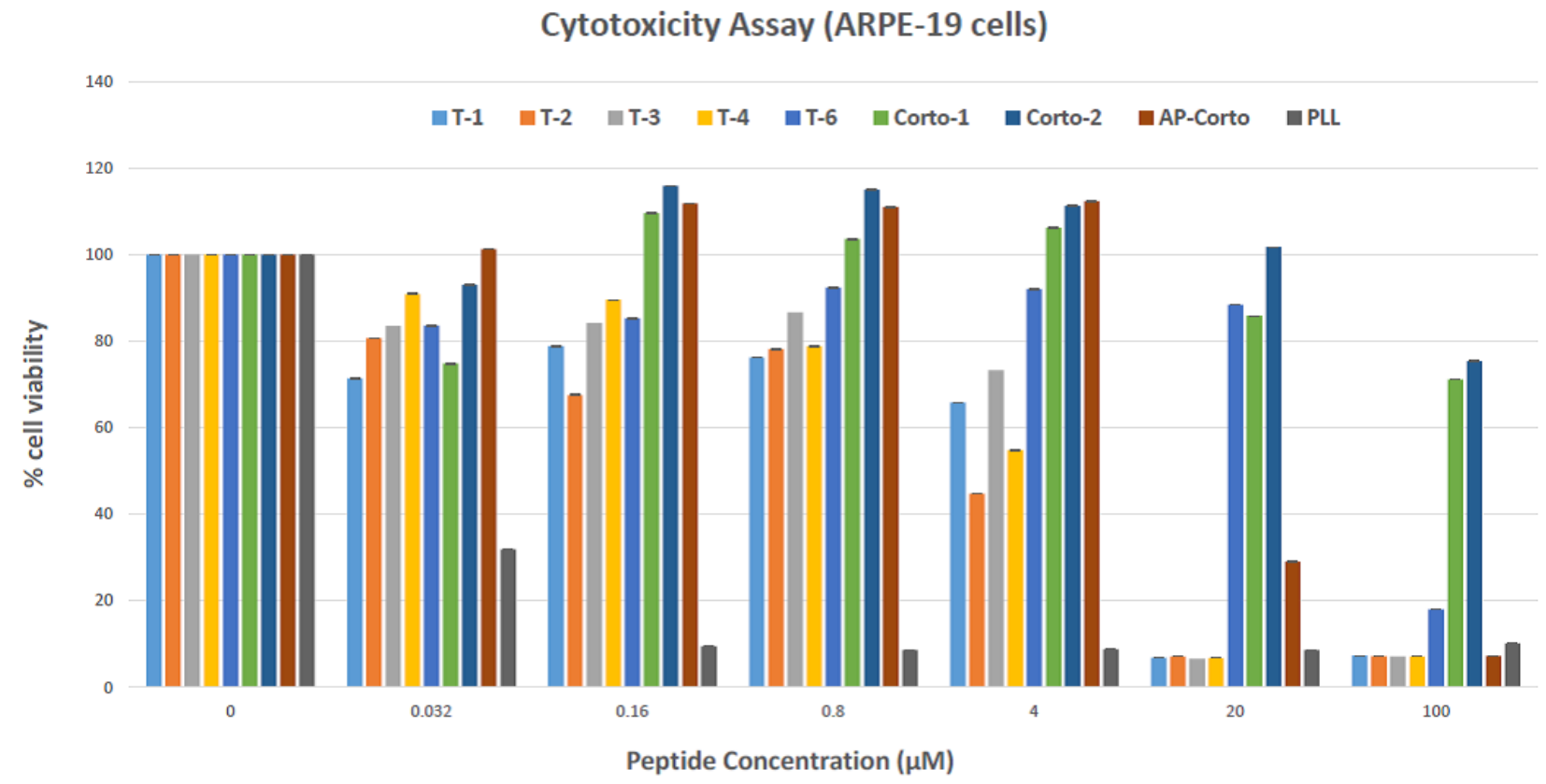

Figure 2: Cytotoxicity of trichogin analogs in ARPE-19 cells. The data are normalized based on the viability of untreated cell and are represented as means $\pm S D(n=3)$.

Almost all the peptides showed very weak cytotoxicity at the concentration up to $0.8 \mu \mathrm{M}$ with cell viability more than $80 \%$. Thus, for the uptake studies $1 \mu \mathrm{M}$ peptide concentration was used. The cell internalization experiments showed that more than $90 \%$ of the cell population has taken up the FITC labeled peptide (Figure 3). 

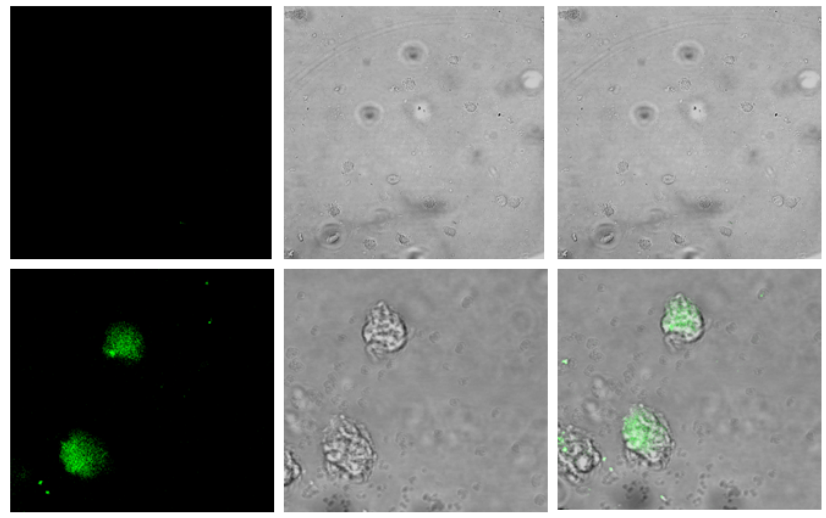

Figure 3: Confocal microscopy images of untreated cells (upper row) and treated with T-5 peptide (lower row). From left to right: fluorescence, transmission and merged images.

In summary, water soluble trichogin analogs described herein showed to be promising membrane permeating molecules with very efficient cell internalization that can be used for drug delivery for the treatment of various diseases of the eye.

\section{Acknowledgements}

The work was supported by Megagrant $\mathrm{N}^{\mathrm{o}}$ 14.W03.31.0025

\section{References}

[1] Del Amo, E. M. et alProg. Retin. Eye Res. 2017, 57, 134-185.

[2] Kamaleddin, M. A. Nanomedicine: NBM, 2017, 13, 1459-1472.

[3] Bhattacharya, M. et al. J. Control. Release. 2017, 251, 37-48.

[4] De Zotti, M. et al. Amino Acids. 2012 Oct;43(4):1761-1777.

[5] Bartucci, R. et al. Biophys. J. 2008, 94, 2698-2705. 